\title{
Journal of Agricultural Science
}

Senior Editor (Animal papers)

Julian Wiseman, University of Nottingham, UK

Senior Editor (Crop \& Soil papers)

Robert E. L. Naylor, Robert E. L. Naylor

The Journal of Agricultural Science publishes papers

concerned with the advance of agriculture and the use of land resources throughout the world. It publishes original scientific work related to strategic and applied studies in all aspects of agricultural science and exploited species, as well as reviews of scientific topics of current agricultural relevance.

The Journal of Agricultural Science publishes papers concerned with the advance of agriculture and the use of land resources throughout the world. It publishes original scientific work related to strategic and applied studies in all aspects of agricultural science and exploited species, as well as reviews of scientific topics of current agricultural relevance.

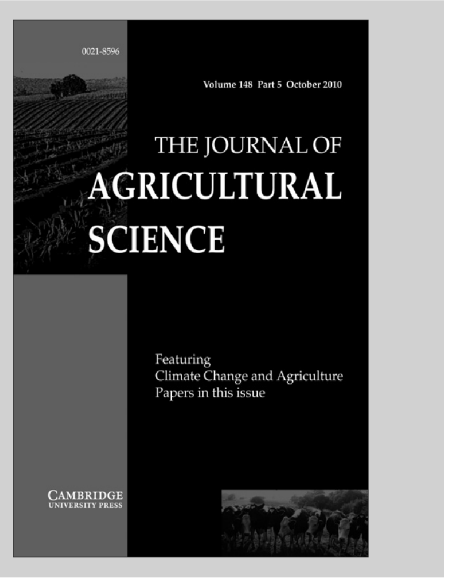

Journal of Agricultural Science is available online at: http://journals.cambridge.org/ags

To subscribe contact Customer Services

in Cambridge:

Phone $+44(0) 1223326070$

Fax $+44(0) 1223325150$

Email journals@cambridge.org

in New York:

Phone (845) 3537500

Fax (845) 3534141

Email

subscriptions_newyork@cambridge.org

Free email alerts

Keep up-to-date with new material - sign up at

journals.cambridge.org/register 


\section{Experimental Agriculture}

The official scientifc journal of the Collegium Internationale Neuro-Psychopharmcologicum (CINP)

\section{Editor-in-Chief}

Dave Harris, Bangor University, UK

Experimental Agriculture publishes the results of original research from any source on the agronomy of field, plantation and herbage crops grown for human or animal food; for industrial purposes; and on systems of agricultural production, particularly in the warmer regions of the world. It is especially concerned with experimental work designed to explain agronomic results in biological and environmental terms. The journal publishes accounts of new experimental techniques, new methods of crop production and discusses problems in countries where production is developing rapidly. There are regular book reviews and occasional, often invited, reviews of research.

\section{Price information}

\section{is available at: http://journals.cambridge.org/eag}

\section{Free email alerts}

Keep up-to-date with new content

http://journals.cambridge.org/eag-alerts

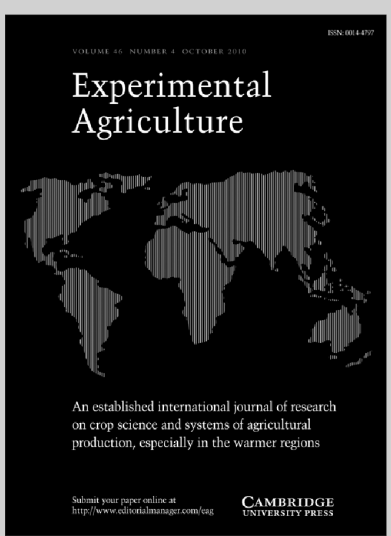

Experimental Agriculture is available online at: http://journals.cambridge.org/eag

To subscribe contact Customer Services

in Cambridge:

Phone $+44(0) 1223326070$

$\mathrm{Fax}+44(0) 1223325150$

Email journals@cambridge.org

in New York:

Phone +1 (845) 3537500

$\mathrm{Fax}+1(845) 3534141$

Email

subscriptions_newyork@cambridge.org 


\section{Seed Science Research}

The official journal of the International Society for Seed Science

\section{Editor-in-Chief}

H.W.M. Hilhorst, Wageningen University, The Netherlands

Seed Science Research is an international journal that publishes original papers, as well as reviews and opinion papers, dealing primarily with the fundamentals of seed research with emphasis on the physiology, biochemistry, molecular biology and ecology of seed development, dormancy and germination. The importance of seeds to propagation, food, biofuel and biodiversity is of increasing interest and therefore submissions on seed genetics, seed biotechnology, seed treatment and seedling establishment are especially encouraged if they are novel and 'seed driven'.

\section{Price information}

\section{is available at: http://journals.cambridge.org/ssr}

\section{Free email alerts}

Keep up-to-date with new content

http://journals.cambridge.org/ssr-alerts

To subscribe contact

Customer Services

in Cambridge:

Phone $+44(0) 1223326070$

$\mathrm{Fax}+44(0) 1223325150$

Email journals@cambridge.org

in New York:

Phone +1 (845) 3537500

$\mathrm{Fax}+1(845) 3534141$

Email

subscriptions_newyork@cambridge.org 


\section{Notes for Authors}

Renewable Agriculture and Food Systems publishes original research on biological, physical, or social science aspects of alternative and renewable agriculture and food systems. We particularly welcome multidisciplinary studies, but papers from a specific discipline are also invited. However, since RAFS readership is much broader than for a single-discipline journal, highly specialized terminology should be explained or avoided. The significance of a statement, or the reasoning behind a conclusion, may have to be spelled out more than in a more specialized journal. See journals.cambridge.org/raf for an explanation of the various categories of articles.

Units. Research papers should use the International (SI, or metric) system throughout. Occasional use of common unit equivalents in parentheses is permitted.

Title Page. The title page should give the following information (all flush left): 1) title of the paper; 2 ) names of the authors; 3 ) affiliation and office address of authors, e-mail of corresponding author, and 4) disclaimers, if any.

Abstract. The abstract should be 200 to 400 words, suitable for readers from a broad range of disciplines. It should avoid highly-specialized terminology that might be appropriate for a single-discipline journal. Take particular care that the significance of the work is made clear, even to readers from a different field.

Key Words. Provide subject matter key words suitable for use in scientific indexing.

References. References are based on the Vancouver system. They should be numbered consecutively in the order in which they first appear in the text using superscript Arabic numerals. Where a reference is cited more than once in the text, use the same number each time. In the reference list please give the names of all authors in the reference, never use "et al." Use full names of journals, institutions, conferences, etc. The reference list uses no quotation marks, italics, boldface or underlining. Only the names of books and periodicals are in initial capitals. Names of papers, book chapters, pamphlets, and bulletins are not capitalized.

\section{Examples:}

1. Leopold, A. 1991. The farmer as a conservationist. In S.L. Flader and J.B. Callicott (eds). The River of the M other of God and Other Essays by Aldo Leopold. University of Wisconsin Press, Madison, WI. p. 255-265.

2. Brink, R.H. Jr, Dubach, P., and Lynch, D.I., 1960. M easurement of carbohydrates in soil hydrolyzates with anthrone. Soil Science 89:157-166.

3. Greenland, D.J., and Szabolcs, I., (eds). 1994. Soil Resilience and Sustainable Land Use. CAB International, Wallingford, UK.

4. Arshad, M.A., and Coen, G.M., 1992. Characterization of soil quality: Physical and chemical criteria. American Journal of Alternative Agriculture 7:25-31.

5. Coale, F.J. 1996. Descriptions of the soil test interpretive categories used by the University of M aryland Soil Testing Laboratory. SFM -3. University of M aryland, College Park.
Footnotes. RAFS does not use bibliographic or substantive footnotes. All bibliographic references should be at the end of the text. Instead of substantive footnotes, include the material in the main text or consider eliminating it.

Manuscript Preparation. The entire manuscript, including abstract and references, should be typed on one side of standard-size paper, double spaced, with margins of at least one inch all around. Starting with the title page, label all pages in the upper right-hand corner with the lead author's last name and the page number. Add line numbers to your manuscript, restarting numbering for each page. Do not use hyphens unless the hyphen is part of the word. Indicate on the title page who the corresponding author is, and supply a present postal address, fax number and email address. The email address is particularly important because page proofs will be sent electronically as a PDF file to the corresponding author for checking (see 'page proofs' section below for more detail). Tables should fit on one page, be numbered consecutively with Arabic numerals, and be on a separate sheet. Every figure and table should be mentioned at least once in the text. A detailed guide to formatting is available on the RAFS homepage at journals.cambridge. org/raf

Submission of Manuscripts. Please submit manuscripts via our manuscript submission and tracking site,

www.edmgr.com/ rafs.

Full instructions for electronic submission are available directly from this site and from journals.cambridge.org/raf.

To facilitate rapid reviewing, communications for peer review will be electronic and authors will need to supply a current e-mail address when registering to use the system.

When submitting manuscripts authors will need to supply:

- M anuscript file.

- Covering letter, stating that the manuscript is an original contribution that has not been published elsewhere in substantially the same form, that it is not currently under consideration elsewhere, and that permission has been obtained for any copyrighted material used.

Copyright. Papers are accepted on the understanding that the work has been submitted exclusively to the Journal. Authors will be supplied with a transfer of copyright form with their proofs, this must be completed and returned to the publisher. Papers will not be published until the signed copyright disclaimer has been received.

Page Proofs. Once typeset, the corresponding author will receive page proofs by email as a PDF file. You will be asked to print the PDF proof and mark any corrections to the printout before mailing back to the proofreader. Alternatively, if you have no corrections or very few they can be returned to the proofreader by email. Full instructions will be sent with the page proofs.

Offprints. Authors are sent a PDF file of the final version of the article. Authors will be e-mailed an offprint order form along with the PDF proof.

\section{A Final Note}

Articles will be considered for publication in the RAFS only when submitted formally, in their final form, and formatted to the style of RAFS. 


\section{Renewable}

\section{Agriculture and \\ Food Systems}

\section{Volume 26 Number 1 March 2011}

\section{Commentary}

Practical lessons for successful long-term cropping systems experiments

William F. Schillinger

\section{New Concepts and Case Studies}

The use of vegetable subproducts from greenhouses (VSG) for animal feed in the Poniente region of Almería

M.A. Márquez, F. Diánez, and F. Camacho

M oving local food through conventional food system infrastructure: Value chain framework comparisons and insights

J. Dara Bloom and C. Clare Hinrichs

\section{Preliminary Reports}

Efficiency of an agrosystem designed for family farming in the pre-Amazon region Alana das Chagas Ferreira Aguiar, Idelfonso Colares de Freitas,

Cristina Silva Carvalho, Paulo Henrique M arques M onroe,

and Emanoel Gomes de M oura

Post-emergence weed control through abrasion with an approved organic fertilizer Frank Forcella, Trevor James, and Anis Rahman

\section{Research Papers}

Hispanic consumers' perceptions toward locally grown ethnic produce: A study

from the east-coast US

Ramu Govindasamy and Venkata S. Puduri

What does 'local' mean in the grocery store? Multiplicity in food retailers'

perspectives on sourcing and marketing local foods

Jonnie B. Dunne, Kimberlee J. Chambers, Katlyn J. Giombolini, and

Sheridan A. Schlegel

Socio-cultural aspects of cow-calf operation persistence in a peri-urban county in lowa

Karie Wiltshire, Kathleen Delate, Jan Flora, and M ary Wiedenhoeft

\section{Review Article}

The potential of herbaceous native Australian legumes as grain crops: a review Lindsay W. Bell, Richard G. Bennett, M egan H. Ryan, and Heather Clarke

\section{Book Review}

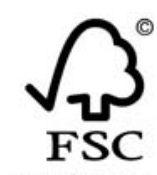

Mixed Sources

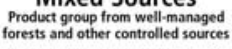

Cert no. SGS-COC-005493 www.fsc.org
1996 forest Stewardship Council 